\title{
A study on the properties of artificial aggregates containing bottom ash from the power plant and waste catalyst slag
}

\author{
Sinae Jo and Seunggu Kang ${ }^{\dagger}$ \\ Department of Advanced Materials Engineering, Kyonggi University, Suwon 443-760, Korea
}

(Received July 31, 2012)

(Revised August 10, 2012)

(Accepted August 14, 2012)

\begin{abstract}
The artificial aggregate composing of coal bottom ash and waste catalyst slag ( $7: 3$, wt $\%$ ) were fabricated using direct sintering method and, the bloating properties of aggregates were investigated as a function of raw material particle size and sintering temperature. Most of the artificial aggregates sintered at over $1150^{\circ} \mathrm{C}$ showed the bloating phenomenon regardless of particle size of the raw materials. Consequently, the specific gravity of the aggregates was drastically decreased to below 1.4. The aggregates containing waste catalyst slag of $90 \mu \mathrm{m}$ under among the W-series specimens, however, did not show the noticeable bloating phenomenon. For the aggregates sintered at lower temperature as 1050 $1150^{\circ} \mathrm{C}$, the specific gravity increased with particle size of raw materials. Also, the water absorption of all aggregates decreased with the sintering temperature. The aggregates fabricated in this study met the lightweight aggregate standard showing the specific gravity 1.7 1.4 and water absorption 8 19\% and, therefore, can be applicable for the various fields.
\end{abstract}

Key words Artificial aggregates, Waste catalyst slag, Bottom ash, Black core, Bloating, Direct sintering, Particle size

\section{화력발전소 바닥재와 폐촉매 슬래그로 제조된 인공골재의 특성 연구}

\author{
조시내, 강승구 ${ }^{\dagger}$ \\ 경기대학교, 수원, 443-760 \\ (2012년 7월 31일 접수) \\ (2012년 8월 10일 심사완료) \\ (2012년 8월 14일 게재확정)
}

요 약 무기계 폐자원인 화력발전소 바닥재(이하 바닥재로 칭함)와 폐촉매 슬래그를 $7: 3$ (무게비)으로 혼합, 성형하고 직화소성법으로 인공골재를 제조한 뒤, 원료들의 입도 및 소성온도가 골재의 발포특성에 미치는 영향을 고찰하였다. 대부 분의 인공골재는 원료 입도에 관계없이 $1150^{\circ} \mathrm{C}$ 이상의 소성온도에서 발포거동을 나타내었으며, 그 결과 비중이 급격히 낮 아져 $1250^{\circ} \mathrm{C}$ 에서 약 1.4 로 수렴하였다. 그러나 폐촉매 슬래그의 입도를 변화시킨 골재 중 가장 작은 입도 $(90 \mu \mathrm{m})$ 를 사용한 시편만은 두드러진 발포특성을 보이지 않았다. $1050 \sim 1150^{\circ} \mathrm{C}$ 의 저온구간에서 소성된 인공골재의 경우, 원료로 사용된 바닥 재와 폐촉매 슬래그 입도가 클수록 비중이 증가하였다. 또한 모든 골재들은 소성온도와 함께 흡수율이 낮아지는 경향을 보 였다. 이 실험에서 제조된 인공골재의 비중은 1.4 1.7, 그리고 흡수율은 $8 \sim 19 \%$ 를 나타내어 경량골재의 기준을 만족함으로 써 다양한 분야에 적용이 가능할 것으로 판단된다.

\section{1. 서 론}

국내에서 발생하는 귀금속을 함유하고 있는 폐촉매는 정유공장에서 발생하는 석유화학 부문에서 나오는 것, 자동차 배기가스에서 배출되는 것 등이 있다. 석유화학

\footnotetext{
Corresponding author

Tel: +82-31-249-9767

Fax: +82-31-249-9774

E-mail: sgkang@kgu.ac.kr
}

촉매로는 백금 계 및 팔라듐 계가 있으며, 촉매의 수명 은 대략 3 4년 정도이다. 자동차 배기가스 촉매의 종류 는 팔라듐, 백금-로듐, 팔라듐-로듐 계 등이 있으며 이들 의 담체로는 $\mathrm{Mg}$-cordierite $\left(\mathrm{MgO} \cdot \mathrm{Al}_{2} \mathrm{O}_{3} \cdot 5 \mathrm{SiO}_{2}\right)$ 조성의 허니컴 구조체가 쓰이고 있다.

최근 산업발전에 따라 백금계 폐촉매의 양이 증가되고 있어, 이로부터 고가인 백금족 금속의 회수 요구가 증대 하고 있다. 폐촉매에서 금속을 회수하는 방법 중 가장 일반적인 것은 폐촉매를 용제와 함께 용융시켜 슬래그를 
얻는 과정에서 백금족 금속을 농축 분리시키는 방식이다. 이때 백금족 원소들의 융점 이상의 온도가 필요하며, 고 온 플라즈마 또는 전기 아크 용융법 등이 사용된다[1]. 그러나 이 방식에 의한 금속 회수는 다량의 중금속을 함 유하는 슬래그를 배출하므로 환경오염 문제에 봉착하고 있다[2].

한편 화력발전소에서 배출되는 석탄 바닥재(이후 바닥 재로 명명)는 보일러 내에서 석탄이 연소될 때 입경이 큰 괴상의 재(ash)들이 하부로 낙하된 것이다. 이는 비산 재와 달리 형상 및 조성이 불균일하여 재활용 원료로 사 용되기에 한계가 있어 거의 매립되고 있는 실정이다 $[3,4]$.

이 논문에서는 바닥재 및 폐촉매 슬래그를 효과적으로 재활용하기 위해 이들을 원료로 인공경량골재를 제조하 고 그 발포 및 경량화 특성을 분석하였다. 특히 각 원료 의 입도 및 소성온도를 실험 변수로 정하고, 인공골재의 물리적 특성과 발포경향을 미세구조 관찰 결과와 연계하 여 고찰하였다.

\section{2. 실험방법}

이 실험에서 사용한 폐기물 원료는 국내 $\mathrm{Y}$ 화력발전 소에서 배출된 바닥재와 국내 $\mathrm{H}$ 사에서 배출된 폐촉매 슬래그이다. 각 원료의 화학적 성분을 $\mathrm{XRF}$ 로 분석하여 Table 1에 나타내었다.

또한 인공골재 제조를 위한 원료의 배합비 및 각 원료 의 입도를 Table 2에 나타내었다. 바닥재와 폐촉매 슬래 그를 $7: 3$ (무게비)의 비율로 혼합하였고 각 원료의 입도 를 $150 \mu \mathrm{m}$ 이하, $150 \sim 100 \mu \mathrm{m}, 100 \sim 90 \mu \mathrm{m}$ 그리고 90 $\mu \mathrm{m}$ 이하의 4 종류로 조절하였다. 시편명에서 $\mathrm{B}$ 는 바닥재 (bottom ash), W는 폐촉매 슬래그(Waste catalyst slag) 를 의미한다.

각 폐기물 원료들은 $110^{\circ} \mathrm{C} / 24 \mathrm{hr}$ 조건으로 건조한 뒤, 분쇄하여 입도제어를 하여 사용하였다. 인공골재의 성형 체는 $20 \mathrm{wt} \%$ 물을 첨가하여 지름 $10 \pm 1 \mathrm{~mm}$ 의 구형 모 양으로 제조하였고, 이를 $1050 \sim 1250^{\circ} \mathrm{C}$ 에서 10 분간 직화 소성하여 인공골재를 제조하였다. 직화소성법은 희망하 는 온도로 가열된 로에 성형체를 넣어 일정시간 소성한 뒤 바로 상온의 외기로 배출시키는 소성방식이다. 사용
Table 2

Batch composition and particle size of raw materials for artificial aggregates

$(\mathrm{wt} \%)$

\begin{tabular}{lllll}
\hline & \multicolumn{2}{l}{$\begin{array}{l}\text { Composition } \\
\text { Specimen }\end{array}$} & \multicolumn{3}{l}{$\begin{array}{l}\text { Particle size } \\
(\mu \mathrm{m})\end{array}$} \\
\cline { 2 - 5 } I.D. & Bottom ash & Waste slag & Bottom ash Waste slag \\
\hline 150B & 7 & 3 & $150 \sim 100$ & $150^{-*}$ \\
100B & 7 & 3 & $100 \sim 90$ & $150^{-}$ \\
90B & 7 & 3 & $90^{-}$ & $150^{-}$ \\
150W & 7 & 3 & $150^{-}$ & $150 \sim 100$ \\
100W & 7 & 3 & $150^{-}$ & $100 \sim 90$ \\
90W & 7 & 3 & $150^{-}$ & $90^{-}$ \\
\hline
\end{tabular}

* ' 150 ' ' means the particles of $150 \mu \mathrm{m}$ and under.

된 원료의 화학조성은 XRF(ZSX-100e, Rigaku, Japan) 를 사용하여 분석하였고, 바닥재와 폐촉매 슬래그의 상 분석을 위해 $\mathrm{CuK} \alpha$ 선이 사용된 $\mathrm{XRD}(\mathrm{X}$-ray diffraction analysis, Pan' alytical, X' pert pro, Netherlands)를 이 용하였다. 또한 제조된 인공경량골재의 비중 및 흡수율 은 KS F 2503 “굵은 골재의 비중 및 흡수율 시험 방법" 으로 측정하였으며, 미세구조는 광학현미경(DCS-105, Sometech-vision, Korea)을 이용하여 관찰하였다.

\section{3. 결과 및 고찰}

Fig. 1은 바닥재와 폐촉매 슬래그를 XRD로 분석한 결 과이다. 바닥재는 대부분 quartz 및 mullite 결정상으로 되어있는 반면, 폐촉매 슬래그는 비정질 상으로 나타났 다. 이는 폐촉매 슬래그를 형성하는 과정에서 용융된 폐 촉매를 급냉하였기 때문으로 생각된다.

한편, 이 연구에서 사용된 원료의 구성 산화물들을 전통 적인 세라믹 3축 성분계에 의거하여 분류하였다(Table 1). 즉, $\mathrm{RO}_{2}(\mathrm{R}=$ metals) 형태의 구조 산화물(frame oxides), $\mathrm{RO}$ 및 $\mathrm{R}_{2} \mathrm{O}$ 형태의 융제 산화물(fluxing oxides) 그리고 $\mathrm{R}_{2} \mathrm{O}_{3}$ 형태의 중성 산화물(neutral oxides)로 분류하였다. 바닥재는 $60.9 \mathrm{wt} \%$ 의 $\mathrm{SiO}_{2}, 29.6 \mathrm{wt} \%$ 의 중성 산화물, 그리고 $5.2 \mathrm{wt} \%$ 의 융제 산화물로 이루어져 있다. 또한 폐촉매 슬래그의 경우 $\mathrm{SiO}_{2}$ 가 $30.3 \mathrm{wt} \%$ 로 상대적으로 적은 양이 함유되어 있으며, $\mathrm{CaO}$ 함유량이 $23.1 \mathrm{wt} \%$ 로 일반 세라믹스 원료에 비해 매우 높게 나타내었다. 또한 바닥재는 미연탄소(C)를 $1.7 \mathrm{wt} \%$ 함유하고 있고, 소성중

Table 1

Chemical compositions of raw materials

$(\mathrm{wt} \%)$

\begin{tabular}{|c|c|c|c|c|c|c|c|c|c|c|c|c|}
\hline \multirow{2}{*}{ Raw materials } & \multirow{2}{*}{$\begin{array}{l}\text { Frame oxide } \\
\mathrm{SiO}_{2}\end{array}$} & \multicolumn{2}{|c|}{ Neutral oxides } & \multicolumn{5}{|c|}{ Fluxing oxides } & \multicolumn{4}{|c|}{ Others } \\
\hline & & $\mathrm{Al}_{2} \mathrm{O}_{3}$ & $\mathrm{Fe}_{2} \mathrm{O}_{3}$ & $\mathrm{CaO}$ & $\mathrm{MgO}$ & $\mathrm{Na}_{2} \mathrm{O}$ & $\mathrm{K}_{2} \mathrm{O}$ & $\mathrm{MnO}$ & $\mathrm{TiO}_{2}$ & $\mathrm{P}_{2} \mathrm{O}_{5}$ & $\mathrm{C}$ & Ig. loss \\
\hline Bottom ash & 60.9 & 25.5 & 4.1 & 1.0 & 0.9 & 0.1 & 3.2 & 0.0 & 0.8 & 0.8 & 1.7 & 1.0 \\
\hline Waste slag & 30.3 & 36.5 & 0.7 & 23.1 & 7.9 & 0.2 & 0.3 & 0.0 & 0.4 & 0.5 & 0.0 & 0.0 \\
\hline
\end{tabular}




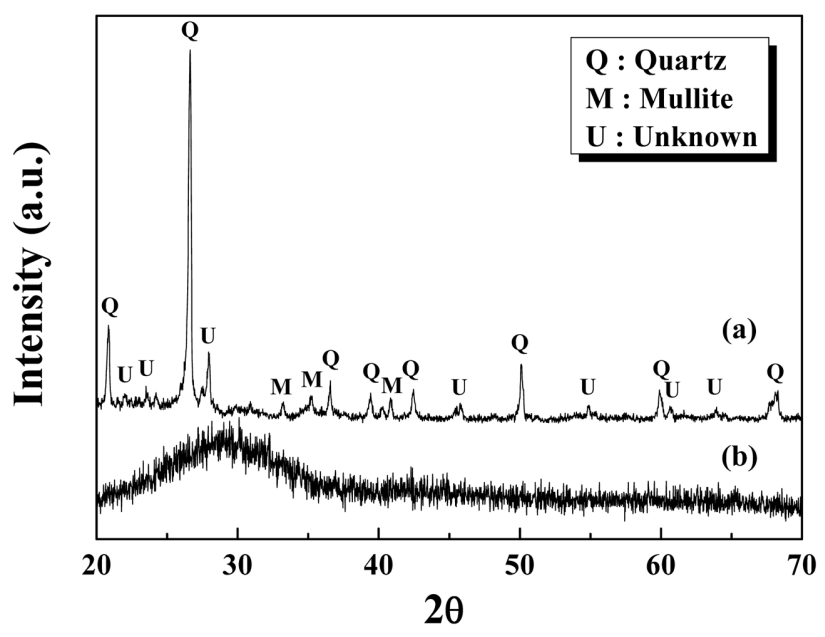

Fig. 1. XRD patterns of (a) bottom ash and (b) waste slag.

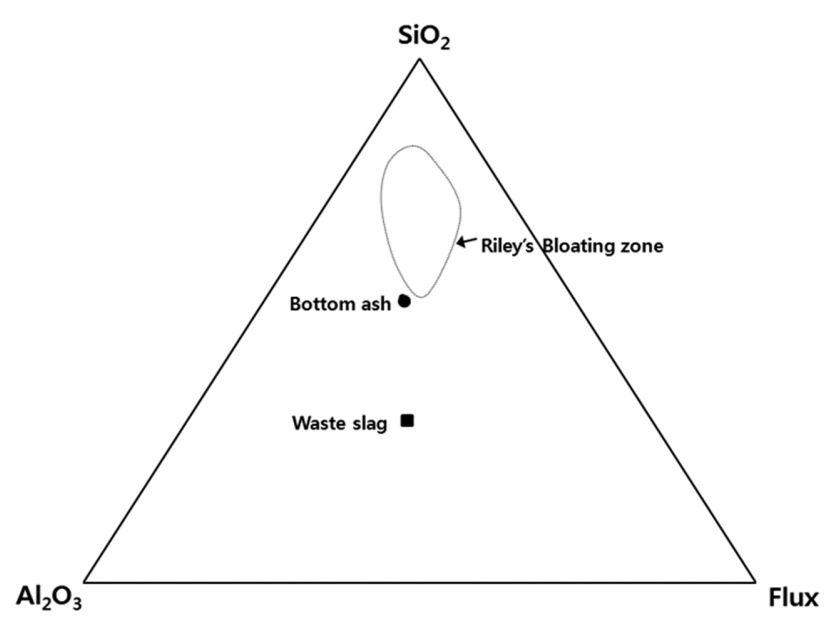

Fig. 2. Ternary diagram of ceramic composition. The area surround by dotted line represents the bloating zones during sintering process presented by Riley [7].

가스를 발생시킬 수 있는 $\mathrm{Fe}_{2} \mathrm{O}_{3}$ 를 $4.1 \mathrm{wt} \%$ 함유하고 있 어 소결시 블랙코어(black core) 기구에 의한 발포특성 을 나타낼 것으로 예상된다 [5, 6].

각 원료의 조성을 세라믹 3축 성분계에 나타낸 것이 Fig. 2이다. 그림 내에 점선으로 표시된 영역은 소성과정 에서 발포가 일어날 수 있는 조성범위로 Riley가 보고한 것이다. Riley는 세라믹스 원료가 가열됨에 따라 점성의 유리질이 생성되며, 이것이 발생 가스를 시편내부에 가 둠으로써 시편이 팽창된다고 발포 메커니즘을 설명하였 다[7]. 이 연구에서 사용된 바닥재(O) 및 폐촉매 슬래 그(ם)는 Fig. 2에 표시된 Riley의 발포영역에 포함되지 않는다. 즉 Riley가 주장하는 발포 조성영역을 기준으로 두 폐기물 모두 $\mathrm{SiO}_{2}$ 함량이 부족한 것을 알 수 있다.

$1050 \sim 1250^{\circ} \mathrm{C}$ 의 온도범위에서 직화소성된 인공골재의 비중을 Fig. 3에 나타내었다. Fig. 3(a)는 폐촉매 슬래그 의 입도를 $150 \mu \mathrm{m}$ 이하로 고정하고, 바닥재의 입도를 3

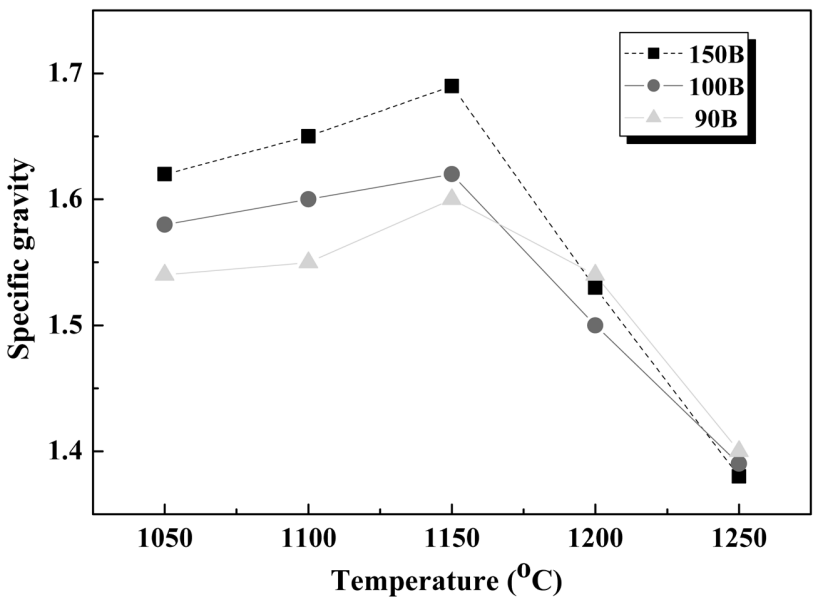

(a)

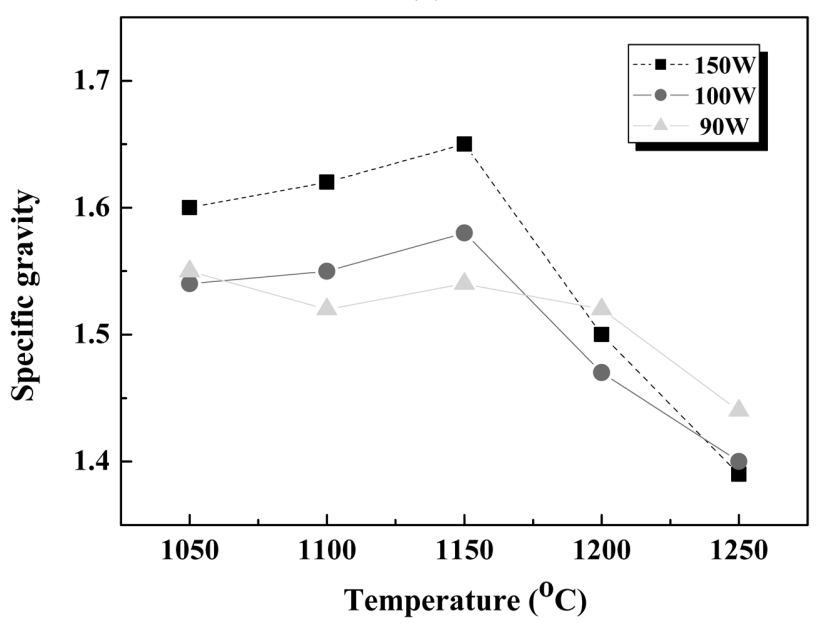

(b)

Fig. 3. Specific gravity of artificial aggregates sintered at 1050 $1250^{\circ} \mathrm{C}$ for $10 \mathrm{~min}$ using direct sintering method in electric furnace.

종류로 변화시켜 제조된 골재(B-계열)의 경우이고, Fig. 3 (b)는 바닥재의 입도는 고정하고, 폐촉매 슬래그의 입도 를 3종류로 변화시킨 골재(W-계열)의 결과이다. B-계열 골재는 $1050 \sim 1150^{\circ} \mathrm{C}$ 범위에서 소성온도와 함께 비중이 증가하는 전형적인 치밀화 소성거동을 보였고, $1150^{\circ} \mathrm{C}$ 이상에서는 비중이 소성온도에 따라 급격히 감소하는 발 포 및 경량화 거동을 나타내었다. 즉 발포 개시온도는 $1150^{\circ} \mathrm{C}$ 이상으로 나타났다. 바닥재의 입도변화는 발포 개시온도에 영향을 주지 않았고, $1250^{\circ} \mathrm{C}$ 에서 소성된 골 재들의 비중도 바닥재 입도변화에 관계없이 모두 약 1.38 을 나타내었다.

그러나, $1150^{\circ} \mathrm{C}$ 이하 소성온도에서는 바닥재의 입도가 클수록 골재의 비중이 높아지는 경향을 보였다. 예를 들 어 $1050^{\circ} \mathrm{C}$ 에서 소성된 골재의 경우, 바닥재의 입도가 제일 큰 $150 \mathrm{~B}$ 시편의 비중은 1.62 였고, 입도가 가장 낮 은 $90 \mathrm{~B}$ 시편의 비중은 1.54 로 나타났다. 입도가 큰 원 료를 사용한 $150 \mathrm{~B}$ 시편이 입도가 작은 시편들에 비해 


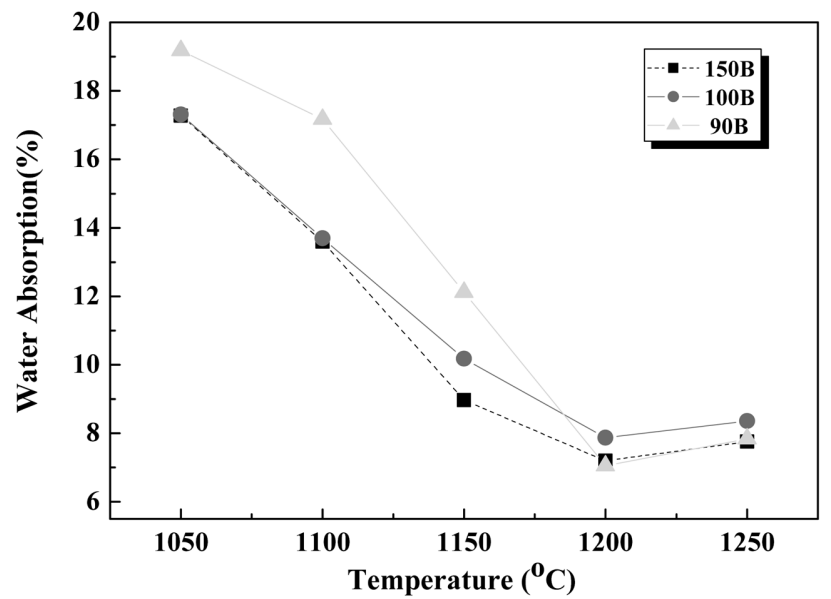

(a)

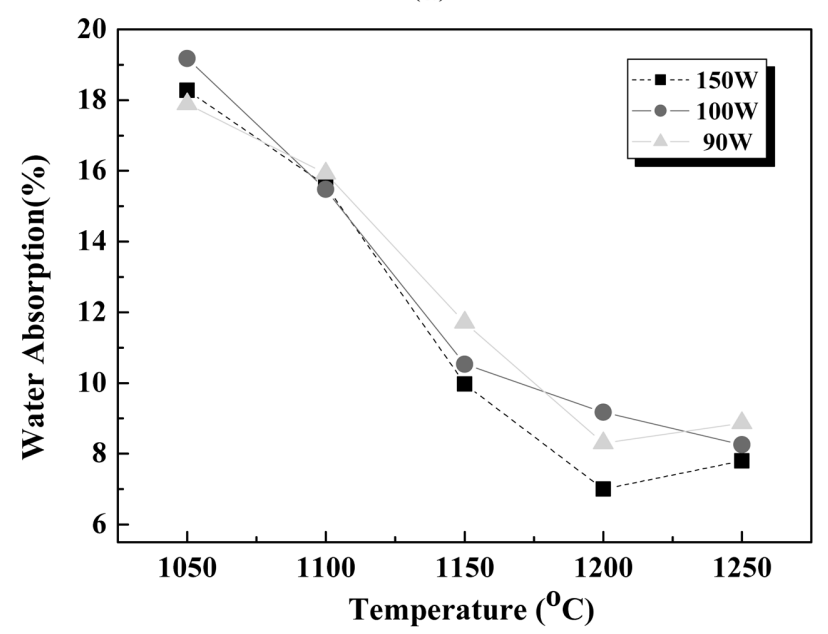

(b)

Fig. 4. Water absorption of artificial aggregates sintered at 1050 $1250^{\circ} \mathrm{C}$ for $10 \mathrm{~min}$ using direct sintering method in electric furnace.

발포온도 이하의 저온소성 구간에서 비중이 높은 것은 입자들 간의 충진(packing)이 잘 되었기 때문으로 생각 된다. $150 \mathrm{~B}$ 시편에 첨가된 바닥재는 $150 \mu \mathrm{m}$ 크기의 채 를 빠져 나온 입자들을 사용한 것이므로, $100 \mathrm{~B}$ 및 $90 \mathrm{~B}$ 시편에 사용된 바닥재들에 비해 입도 분포가 더 넓다. 따라서, $150 \mathrm{~B}$ 시편은 원료분말 혼합시 충진도가 $100 \mathrm{~B}$ 또는 $90 \mathrm{~B}$ 보다 높았을 것이며, 이것이 소성 후 더 높은 비중 값의 원인이 되었다고 생각된다.

한편, 폐촉매 슬래그의 입도를 변화시켜 제조된 W-계 열 골재의 비중은, $90 \mathrm{~W}$ 시편을 제외하고는, B-계열 골 재 경우와 비슷한 경향을 보여주었다 [Fig. 3(b)]. 90W 골재는 전 소성온도 범위에서 온도 증가에 따른 치밀화 거동이 없이 비중이 점차 감소하였고 또한 발포 개시온 도가 뚜렷이 나타나지도 않았다. $90 \mathrm{~W}$ 골재는 $1250^{\circ} \mathrm{C}$ 로 소성하여도 비중이 1.45 로 다른 대부분의 골재 비중(약 1.4)에 비하여 경량화가 잘 이루어지지 않은 것으로 판 단된다. 가장 작은 입도를 갖는 $90 \mathrm{~W}$ 시편에서 발포거동
이 잘 나타나지 않은 것은, $150 \mathrm{~W}$ 또는 $100 \mathrm{~W}$ 경우 보 다 입도분포가 좁은 폐촉매 슬래그를 사용하였으므로 혼 합시 입자 충진이 상대적으로 낮았기 때문으로 생각된다. 입자 충진도가 낮으면 소성과정 중에 가스가 시편 밖으 로 쉽게 빠져 나가므로, 발포경향이 낮아진다. 한편 $1250^{\circ} \mathrm{C}$ 에서 소성한 경우, $\mathrm{W}$-계열 골재의 비중은 1.39 1.44 으로써, B-계열 골재들의 $1.38 \pm 0.01$ 에 비해, 발포된 시편간 비중 분포가 더 큰 것으로 나타났다.

제조된 인공골재의 소성온도에 따른 흡수율 결과를 Fig. 4에 나타내었다. 바닥재의 입도를 조절한 B-계열 골재의 경우[Fig. 4(a)], 소성온도 증가에 따라 흡수율이 감소하는 경향을 보였다. 그러나 소성온도에 따라 감소 하던 흡수율이 $1250^{\circ} \mathrm{C}$ 의 고온에서 약간 증가하였다. $1050 \sim 1150^{\circ} \mathrm{C}$ 소성범위에서 골재 종류간 흡수율은 최대 $3 \%$ 이상 차이가 났으며, $150 \mathrm{~B}$ 시편의 흡수율이 $100 \mathrm{~B}$ 및 $90 \mathrm{~B}$ 시편보다 높았다. 그러나 $1200^{\circ} \mathrm{C}$ 이상에서는 입 도 변화에 따른 흡수율 변화는 거의 없었다. 소성온도의 증가에 따라 흡수율이 감소하는 경향은 $\mathrm{W}$-계열 골재에 서도 유사하였다[Fig. 4(b)]. 또한 $100 \mathrm{~W}$ 시편을 제외하 고는 $1250^{\circ} \mathrm{C}$ 소성시 흡수율이 약간 증가하는 현상도 $\mathrm{B}-$ 계열 골재와 비슷하게 나타났다. 그러나, $1150^{\circ} \mathrm{C}$ 이하의 소성구간에서 $\mathrm{W}$-계열 골재간 흡수율 차이는 $\mathrm{B}$-계열 골 재들에 비해 크지 않았다. 이로부터 이 실험에서 제조된 골재는 소성온도 및 원료 입도를 제어함에 따라 흡수율 을 8 19\% 범위에서 발현시킬 수 있음을 확인하였다.

소성된 골재의 외관을 광학현미경으로 관찰하여 Fig. 5 에 나타내었다. 골재의 표면은 저온의 소성온도에서는 옅은 붉은색을 나타냈고, 고온으로 갈수록 어두운 갈색 으로 변하였다. 소성골재 표면이 붉은색인 것은 $\mathrm{Fe}_{2} \mathrm{O}_{3}$ 의 존재 때문이며, 어두운 갈색인 것은 산화철이 환원되기 때문으로 알려져 있다[8].

한편 $1150^{\circ} \mathrm{C}$ 이하 온도로 소성된 골재 표면에는 액상 을 관찰할 수 없었으나, $1200^{\circ} \mathrm{C}$ 이상 온도로 소성된 대 부분의 골재 표면에는 약간의 액상이 형성된 것을 육안 으로 확인할 수 있었다. 세라믹 소성 과정에서 표면에 액상이 형성되면 시편 내부가 외기와 차단되고, 동시에 가스가 방출되지 못하고 팽창하여, 시편은 발포거동을 나타낸다고 보고되어 있는데[7], 이는 $1150^{\circ} \mathrm{C}$ 이상에서 제조된 인공골재의 비중이 급격히 낮아진 결과(Fig. 3)와 시편 표면에 액상이 형성된 관찰결과(Fig. 5)를 잘 설명 해준다.

인공경량골재의 절단면 미세구조사진을 Fig. 6에 나타 내었다. B-계열 골재 중 $150 \mathrm{~B}$ 및 $100 \mathrm{~B}$ 시편은 소성온 도 $1150^{\circ} \mathrm{C}$ 에서부터 중심부가 검은색으로 변하는 블랙코 어(black core) 현상이 발생되었다. 이 실험에서 사용된 바닥재와 폐촉매 슬래그는 Fig. 2에 보인 바와 같이 Riley가 주장한 발포조성에 포함되지 않았으나, 각각을 


\begin{tabular}{|c|c|c|c|c|c|}
\hline $\begin{array}{l}\text { Sintering } \\
\text { Temp. } \\
\left({ }^{\circ} \mathrm{C}\right) \\
\text { Specimen } \\
\text { I.D. }\end{array}$ & 1050 & 1100 & 1150 & 1200 & 1250 \\
\hline $150 \mathrm{~B}$ & & & & & \\
\hline $100 \mathrm{~B}$ & & & & & \\
\hline $90 \mathrm{~B}$ & & & & & \\
\hline $150 \mathrm{~W}$ & & & & & \\
\hline $100 W$ & & & & & \\
\hline $90 \mathrm{~W}$ & & & & & \\
\hline
\end{tabular}

Fig. 5. Optical microscopic photographs for the external appearance of artificial aggregates sintered at $1050 \sim 1250^{\circ} \mathrm{C}$ for $10 \mathrm{~min}$ in electric furnace.

\begin{tabular}{|c|c|c|c|c|c|}
\hline $\begin{array}{l}\text { Sintering } \\
\text { Temp. } \\
\left({ }^{\circ}\right) \\
\text { Specimen } \\
\text { I.D. }\end{array}$ & 1050 & 1100 & 1150 & 1200 & 1250 \\
\hline 150B & & & & & \\
\hline $100 \mathrm{~B}$ & & & & & \\
\hline $90 \mathrm{~B}$ & & & & & \\
\hline $150 \mathrm{~W}$ & & & & & \\
\hline $100 W$ & & & & & \\
\hline $90 \mathrm{~W}$ & & & & & \\
\hline
\end{tabular}

Fig. 6. Optical microscopic photographs for the cut section of artificial aggregates sintered at $1050 \sim 1250^{\circ} \mathrm{C}$ for 10 min in electric furnace. 
$7: 3$ (무게비)으로 혼합하고, $1150^{\circ} \mathrm{C}$ 이상의 온도로 소성 하면 블랙코어 형성에 의한 발포현상을 나타내었다.

한편 낮은 입도를 가진 $90 \mathrm{~B}$ 및 $90 \mathrm{~W}$ 골재는 더 높은 온도인 $1200^{\circ} \mathrm{C}$ 에서 블랙코어가 형성되기 시작하였다. 블랙코어 현상은 시편 내에 존재하는 $\mathrm{Fe}_{2} \mathrm{O}_{3}$ 가 탄소 산 화 및 외기 차단에 의해 환원되기 때문이다 $[9,10]$. 입도 가 작은 원료를 사용한 골재는 입자 충진도가 낮아 저온 소결시 탄소에서 기인된 가스가 시편 밖으로 쉽게 빠져 나가므로 블랙코어 발현이 어려웠던 것으로 생각된다. Park 등은 세라믹 원료에 적정량의 탄소가 존재할 경우, 소성온도가 높아짐에 따라 블랙코어 면적이 증가한다고 하였다[5]. 이 실험에서 제조된 골재들은 소성온도의 증 가에 따라 붉은색 표피(shell) 두께는 감소하고 내부의 블랙코어 면적은 증가하였다. 이로부터 본 골재 원료 중 바닥재에 포함된 $1.7 \mathrm{wt} \%$ 탄소는 블랙코어를 일으키기 에 충분한 양인 것으로 보인다.

$1200^{\circ} \mathrm{C}$ 이상의 온도에서 골재내부를 가로지르는 방사 상 균열(radial crack)이 발생하였다. 이러한 방사상 균열 은 내부에 있던 기체가 고온에서 급격히 팽창하면서 일 시에 빠져나가는 과정에서 발생된 것으로 보인다. 흥미 로운 것은, $1150^{\circ} \mathrm{C}$ 에서 소성된 골재들은 $90 \mathrm{~B}$ 및 $90 \mathrm{~W}$ 를 제외하고 모두 블랙코어가 발생되었지만 비중은 다른 소성온도에서 제조된 골재들보다 높다는 것이다. 이 현 상이 방사상 균열 때문일 가능성이 높으나 정확한 규명 은 추후 연구가 필요하다. 이 실험에서 제조된 골재들은 $1150^{\circ} \mathrm{C}$ 이상의 소성온도에서 발포 경향을 나타냈지만, 비중 1.0 이하의 초경량 특성은 보이지 않았다. 그 이유 는 바닥재 및 폐촉매 슬래그의 조성이 $\mathrm{SiO}_{2}$ 성분 부족 으로 Riley가 주장한 발포 영역으로부터 벗어나있기 때 문으로 생각된다. 발생된 가스를 시편 내부에 가두어 팽 창시키려면 충분한 량의 액상이 형성되어야 하는데, 이 실험에 사용된 원료는 $\mathrm{SiO}_{2}$ 성분이 낮아 유리질 액상형 성이 부족했던 것으로 판단된다.

이상의 결과로부터, 이 연구에서 제조된 시편은 바닥 재와 폐촉매 슬래그의 입도변화 및 소성온도에 따라 1.4 1.7의 비중과, 8 19\%의 흡수율을 나타내었으며 따 라서 다양한 비중 및 흡수율을 갖는 기능성 인공경량골 재로의 활용이 가능하다고 생각된다.

\section{4. 결 론}

이 연구에서는 바닥재와 폐촉매 슬래그를 $7: 3$ 의 무게 비로 혼합한 후 직화소성법으로 인공경량골재를 제조하 였다. 바닥재 입도를 조절한 B-계열 골재와 폐촉매 슬래 그 입도를 조절한 $\mathrm{W}$-계열 골재 모두 $1150^{\circ} \mathrm{C}$ 보다 높은 온도로 소성하였을 때 비중이 급격히 낮아지는 발포 경
향을 보였다. $1050 \sim 1150^{\circ} \mathrm{C}$ 의 저온소성 구간에서는 바닥 재와 폐촉매 슬래그의 입도가 낮을수록 골재의 비중이 낮아지는 경향을 보였으나, 고온소성 구간에서는 원료 입도가 골재의 비중에 큰 영향을 주지는 않았다. 모든 골재의 발포 개시온도는 $1150^{\circ} \mathrm{C}$ 보다 높은 온도였으며 이는 시편 표면에 약간의 액상이 형성된 온도와 일치하 였다.

그러나 B- 및 W-계열 골재 중 가장 작은 입도 $(90 \mu \mathrm{m})$ 를 사용한 시편들은 온도에 따른 발포거동이 두드러지지 않았으며, 특히 $90 \mathrm{~W}$ 골재가 $90 \mathrm{~B}$ 보다 더 발포경향이 낮았다. 제조된 골재의 흡수율은 B- 및 W-계열 모두 소 성온도 증가에 따라 전반적으로 감소하였으나, 같은 소 성온도의 경우 흡수율의 변동은 $\mathrm{B}$-계열이 $\mathrm{W}$-계열 골재 에 비해 더 크게 나타났다.

$1200^{\circ} \mathrm{C}$ 이상의 온도에서 골재내부에 방사상 균열이 형성될 확률이 높았으며, 이는 내부에 있던 많은 양의 기체가 일시에 빠져나가면서 형성된 것으로 보인다. 이 연구를 통하여 바닥재와 폐촉매 슬래그를 재활용하여 인 공골재를 제조함에 있어, 원료들의 입도를 조절하고 $1050 \sim 1250^{\circ} \mathrm{C}$ 에서 소성함으로써 비중은 $1.3 \sim 1.7$, 흡수율 은 8 19\%를 나타내는 비구조용 경량골재 발현이 가능 하였으며, 따라서 향후 기능성 경량 담체 등으로의 적용 이 기대된다.

\section{감사의 글}

본 연구는 2012학년도 경기대학교 대학원 연구원장학 생 장학금 지원에 의하여 수행되었음.

\section{참 고 문 헌}

[1] D.Y. Shin, Jeon-Ju University Graduate School a master's thesis (2010).

[2] J.C. Lee, Recycling white paper, Resource Recycling R\&D Center, Gyeonggi-do (2004).

[3] S.U. Shin, S. Kumar, T.U. Jung and B.W. Shin, "The strength and characteristic of PCC bottom ash", J. Kor. Geo-Environ. Soc. 8[2] (2007) 57.

[4] K.D. Kim, J.H. Kim, Y.T. Kim, S.G. Kang and K.G. Lee, "Production of lightweight aggregates using power plant reclaimed ash", J. Kor. Ceram. Soc. 47[6] (2010) 583.

[ 5 ] J.Y. Park, Y.T. Kim, K.G. Lee, S.G. Kang and J.H. Kim, "The mechanism of black core formation," J. Kor. Cryst. Growth and Cryst. Tech. 15[5] (2005) 208.

[6] J.C. Hostetter and H.S. Roberts, "Notes on the Dissociation of ferric oxide dissolved in glass and its relation to the color of iron-bearing glasses," J. Am. Ceram. Soc. 4[11] (1921) 927. 
[ 7 ] C.M. Riley, "Relation of chemical Properties to the bloating of clays", J. Am. Ceram. Soc. 34[4] (1951) 121.

[ 8 ] V.Z. Abdrakhimov and E.C. Abdrakhimova, "Formation of the black core in high-speed firing of floor tiles," Glass and Ceramics 56[8] (1999) 30.

[9] M.A. Kang and S.G. Kang, "Characterization of artifi- cial aggregates fabricated from coal bottom ash containing much undurned carbon", J. Kor. Cryst. Growth and Cryst. Tech. 21[1] (2011) 47.

[10] K.D. Kim and S.G. Kang, "Properties of artificial aggregates fabricated with various heating conditions", J. Kor. Cryst. Growth and Cryst. Tech. 20[6] (2010) 301. 